\title{
Octreotide prevents growth factor-induced proliferation of bovine retinal endothelial cells under hypoxia
}

\author{
A Baldysiak-Figiel, G K Lang, J Kampmeier and G E Lang \\ Department of Ophthalmology, University of Ulm, Ulm, Germany \\ (Requests for offprints should be addressed to G E Lang, Department of Ophthalmology, University of Ulm, 89075 Ulm, Germany; \\ E-mail: gabriele.lang@medizin.uni-ulm.de)
}

\begin{abstract}
Ocular diseases such as proliferative diabetic retinopathy are the major cause of blindness in industrialized countries. The main pathologic features of these diseases are hypoxia and overproduction of growth factors resulting in pathologic proliferation of endothelial cells and new vessel formation. Particularly, hypoxia and growth factors, such as VEGF, IGF-1, bFGF and TGF $\beta_{2}$, show a complex interaction in the onset and progression of the diseases. Therefore, to date, most therapeutic strategies for proliferative retinopathies have targeted proliferation of endothelial cells evoked by growth factors. Recently, a synthetic analog of somatostatin, octreotide, has been shown to inhibit the proliferation of various cells in vitro, including endothelial cells. In this study, we have investigated the proliferative response of bovine retinal endothelial cells (BREC) to growth factors under hypoxic conditions and the modulation by octreotide. We found a
\end{abstract}

dose-dependent increase of cell proliferation with VEGF, IGF-1 and bFGF, and inhibition of hypoxia-induced cell proliferation with $\mathrm{TGF}_{2}$. Moreover, growth factorinduced, but not hypoxia-induced, cell proliferation was attenuated in the presence of octreotide. In contrast, TGF $\beta_{2}$ abolished hypoxia-induced BREC proliferation. Similar to octreotide BIM23027, a somatastatin receptor subtype 2 (SSTR2) receptor agonist was able to attenuate the growth factor-induced proliferation of BREC expressing mRNA and protein for SSTR2. Therefore, we postulate that octreotide exerts its effects mainly through binding to the SSTR2. Taken together, our findings point to octreotide as a promising candidate for the treatment of eye disorders involving growth factor-dependent proliferation of endothelial cells.

Journal of Endocrinology (2004) 180, 417-424

\section{Introduction}

The eye is one of the best models of blood vessel formation due to the diversity of angiogenic processes taking place throughout development and in adults (Risau 1994, Campochiaro 2000). During development, the eye is vascularized by either vasculogenesis, which means assembling of vessels from newly differentiated endothelial cells, or angiogenesis, which means sprouting of endothelial cells from pre-existing vessels (Battegay 1995, Hughes et al. 2000). In adults, new blood vessel formation occurs predominantly through angiogenesis (Campochiaro 2000). Although angiogenesis plays a crucial role in vessel repair and wound healing, it also accounts for pathologic events, such as tumor growth, as well as retinal and choroidal neovascularization (Risau 1994, Battegay 1995). Regardless of the pathologic or physiological nature of vascularization, the establishment of capillary networks requires a complex series of cellular events which are initiated and modulated by a multitude of growth factors including vascular endothelial cell growth factor (VEGF), insulin-like growth factor-1 (IGF-1), basic fibroblast growth factor (bFGF) and transforming growth factor $\beta_{2}$ $\left(\mathrm{TGF} \beta_{2}\right)$, and further affected by systemic conditions such as hyperoxia and hypoxia (Wiedemann 1992, Battegay 1995, D’Amore 1994, Campochiaro 2000).

Vascular endothelial cell growth factor (VEGF) exerts its action through two tyrosine kinase receptors, namely VEGF receptor 1 (VEGFR1) and VEGFR2 (Campochiaro 2000). Binding of VEGF to VEGFR2 results in differentiation of the angioblasts into endothelial cells, whereas assembly of endothelial cells into tubes is mediated via activation of VEGFR1 (Campochiaro 2000). Insulin-like growth factor-1 (IGF-1) binds to IGF receptors (types I and II), and this binding is modulated by a system of IGF-binding proteins (IGFBP) and IGFBP proteases (Jones \& Clemmons 1995, Feldmann et al. 2000). The consequence of IGF stimulation is the activation of endothelial cells as manifested by cell proliferation and migration (King et al. 1983, Grant et al. 1986, 1987, 1993b, Wilson et al. 2001). Basic fibroblast growth factor (bFGF) is a ligand of FGF tyrosine kinase receptors coupled to various downstream signaling pathways affecting cell survival, mitosis, differentiation, adhesion and 
motility (Gospodarowicz et al. 1987, Bensaid et al. 1992). Transforming growth factor $\beta_{2}\left(\mathrm{TGF} \beta_{2}\right)$ with its serine/ threonine kinase receptors can stimulate or inhibit endothelial cell proliferation and control synthesis and degradation of the extracellular matrix (ECM) (Madri et al. 1988, Rifkin et al. 1993, Katsura et al. 2000). Additional spin to the system of growth factors affecting endothelial cells proliferation is provided by systemic conditions such as hypoxia/ischemia (Das et al. 2001). Hypoxia is essentially a pathologic condition and is thought to be the main driving force for retinal neovascularization (Yan et al. 2001, Humar et al. 2002). There are several ways by which hypoxia affects retinal neovascularization. Most importantly, hypoxia affects cell proliferation by induction of $G_{1}$ cell cycle arrest (Gardner et al. 2001). The mechanism of this arrest is thought to be related to the mammalian target of rapamycin (mTOR) signaling pathway, which plays a central role in regulating cellular growth and induction of genes such as cyclin D (Schmelzle \& Hall 2000, Humar et al. 2002). Additionally, hypoxiainducible factor 1 alpha (HIF-1 $\alpha$ ) regulates metabolic genes and thus the availability of nutrients, which in turn affects mTOR (Humar et al. 2002). In pericytes, hypoxia causes decreased expression of TGF $\beta_{2}$, a major inhibitor of endothelial cell proliferation (Antonelli-Orlidge et al. 1989). It has been also reported that hypoxia positively influences the expression of growth factor receptors such as flt-1 (Gerber et al. 1997). Moreover, recent work by Hackett et al. (2002) points to hypoxia as a possible factor influencing angiopoietin-2 (Ang2) expression within areas of neovascularization in the retina. Hypothetically, Ang2 could increase the response of endothelial cells to VEGF as a result of the disruption of cell-cell contacts and extracellular matrix interaction. In general, growth factors seem to exert complex interactions under hypoxia to induce cell proliferation in eye disorders. Consequently, therapeutic strategies for diabetic retinopathy are currently focusing on the identification of pathways and receptors which would be able to antagonize VEGF-, IGF-1-, bFGF- or hypoxiadependent action on endothelial cell proliferation. Promising candidates for such an action are somatostatin and its receptors (Boehm et al. 2001). The family of seven transmembrane domain G protein-coupled somatostatin receptors comprises five members termed SSTR1-5, which bind somatostatin 14 and somatostatin 28 as physiological ligands (van Hagen et al. 2000, Davis et al. 2001). The activation of the receptors leads to pronounced inhibition of adenylate cyclase and activation of tyrosine phosphatases. Additionally, binding of somatostatin to SSTR 5 decreases the activity of the MAPK pathway, as opposed to the stimulatory action of SSTR 1 and -4 . Those signaling profiles mainly point to SSTR $2,-3$ and -5 as isoforms linked to inhibition of cell proliferation (Buscail et al. 1995, Danesi et al. 1997). The recently produced synthetic somatostatin receptor ligand, octreotide, shows high affinity binding to SSTR 2 and -5 , moderate binding affinity to SSTR 3 and low affinity to both SSTR1 and -4. Accordingly, octreotide has been shown to exert antiproliferative effects on somatostatin receptor-expressing cells (Bruns et al. 2000). To date, octreotide has been found to inhibit the proliferation of human endothelial cells HUVEC-C (Danesi et al. 1997).

In our work, we have investigated the proliferative response of bovine retinal endothelial cells (BREC) to octreotide or the growth factors including VEGF, IGF-1, $\mathrm{bFGF}$ and $\mathrm{TGF} \beta_{2}$ under hypoxia, systemic conditions associated with the development of various eye disorders. We provide evidence that octreotide is a potent inhibitor of growth factor-induced cell proliferation.

\section{Materials and Methods}

\section{Preparation of retinal endothelial cell cultures}

Bovine eyes were obtained from a local slaughterhouse. The eyes were freed from muscles, conjunctiva and connective tissues, and briefly immersed in $70 \%$ ethanol followed by $30 \mathrm{~min}$ soaking in a $5 \%$ penicillin/ streptomycin solution (Gibco) and rinsing with sterile water. The vascular retina was dissected, freed from the underlying pigmented retina and homogenized in Hanks' balanced salt solution (HBSS) containing $0 \cdot 1 \%$ bovine serum albumin (BSA), supplemented with 1\% penicillin/ streptomycin. The fragments of vascular retina were collected on $70 \mu \mathrm{m}$ nylon sieves and incubated in PBS containing $20 \mathrm{U} / \mathrm{ml}$ type 2 DNA-ase I (Sigma) and $0 \cdot 1 \%$ collagenase type I (Roche) at $37{ }^{\circ} \mathrm{C}$ for $90 \mathrm{~min}$ with agitation. The cell suspension was washed three times with HBSS-BSA and incubated with Dynabeads coated with antibody against CD31 (Dynal, Hamburg, Germany) in $\mathrm{PBS} / 0 \cdot 1 \% \mathrm{BSA}$ for $15 \mathrm{~min}$ at $4{ }^{\circ} \mathrm{C}$ with gentle tilting and rotation. The endothelial cells bound to the beads were collected with a magnetic particle concentrator (MPC; Dynal), thoroughly washed and resuspended in Endothelial Microvascular Cell Growth Medium (ECGM) (PromoCell, Heidelberg, Germany). The cells were seeded on six-well plates coated with human fibronectin $(10 \mu \mathrm{g} / \mathrm{ml}$; Becton Dickinson, Heidelberg, Germany) and maintained in a humidified atmosphere of $5 \% \mathrm{CO}_{2}$ at $37^{\circ} \mathrm{C}$. The medium was renewed every third day. After 7 days, the cells at passage number 0 were subcultured in $1: 3$ ratio into $35 \mathrm{~cm}^{2}$ culture flasks and than regularly passaged every 3 days. For hypoxia, cultures were incubated in a hypoxia incubator (Heraeus, Hanau, Germany) with a gas mixture containing $5 \% \mathrm{O}_{2}$ and $5 \% \mathrm{CO}_{2}$ balanced with nitrogen.

\section{Proliferation assay}

For DNA synthesis assays, cells were seeded on 96-well, flat-bottom plates (Nunc, Roskilde, Germany) at a density 
A

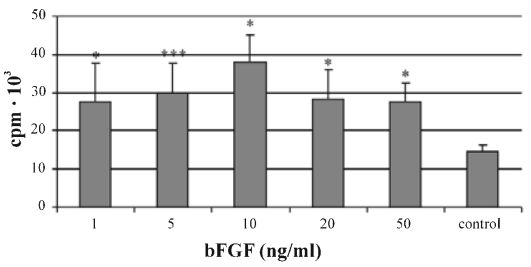

$\mathbf{C}_{40}$

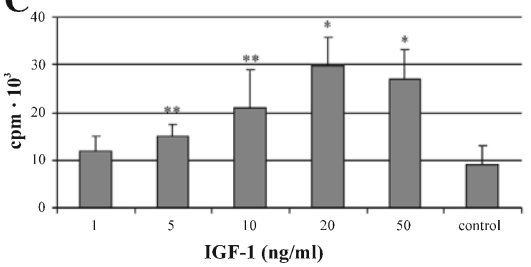

B

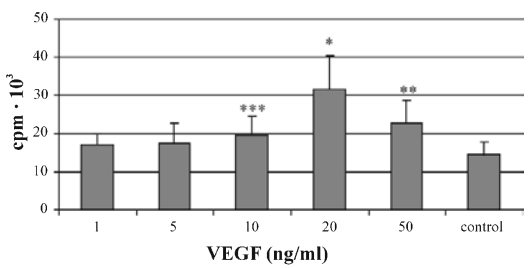

D

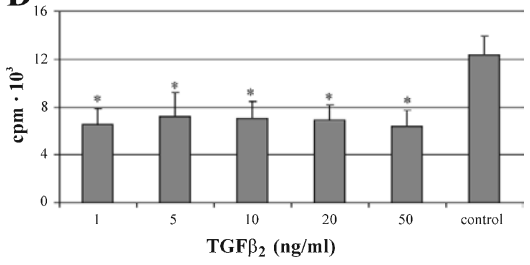

Figure 1 Regulation of BREC proliferation by growth factors under hypoxia. The cells were starved for $24 \mathrm{~h}$ in serum deprived medium with $5 \% \mathrm{O}_{2}$ atmosphere and then exposed for another $24 \mathrm{~h}$ to $1 \mu \mathrm{Ci} / \mathrm{ml}\left[{ }^{3} \mathrm{H}\right]$ thymidine in the presence of either bFGF, VEGF, IGF-1 or $\mathrm{TGF} \beta_{2}$ at the indicated concentrations. $\left[{ }^{3} \mathrm{H}\right]$ thymidine incorporation was measured by liquid scintillation counting. bFGF (A), VEGF (B) and IGF-1 (C) robustly induced BREC proliferation at concentrations of $10 \mathrm{ng} / \mathrm{ml}(2 \cdot 7 \pm 0 \cdot 6$-fold $), 20 \mathrm{ng} / \mathrm{ml}(2 \cdot 2 \pm 0 \cdot 6$-fold $)$ and $20 \mathrm{ng} / \mathrm{ml}$ $(3 \cdot 8 \pm 1 \cdot 8$-fold $)$ respectively. (D) TGF $\beta_{2}$ potently decreased the proliferation of BREC at all concentrations tested $\left(n=3 ;{ }^{*} P<0 \cdot 0001,{ }^{* *} P<0 \cdot 001,{ }^{* * *} P<0 \cdot 01\right)$.

of $5 \times 10^{4}$ cells $/ \mathrm{ml}$ in ECGM medium and allowed to accommodate for 1 day. To assess the role of oxygen conditions on BREC proliferation, the ECGM medium was changed to serum-free medium, and the cells were cultured for $48 \mathrm{~h}$ under normoxia $\left(21 \% \mathrm{O}_{2}, 5 \% \mathrm{CO}_{2}\right)$ or hypoxia $\left(5 \% \mathrm{O}_{2}, 5 \% \mathrm{CO}_{2}\right)$. During the last $24 \mathrm{~h}$, the culture medium was additionally supplemented with $1 \mu \mathrm{Ci} / \mathrm{ml}\left[{ }^{3} \mathrm{H}\right]$ thymidine. Subsequently, the cells were washed, dissociated in $0 \cdot 25 \%$ trypsin-EDTA and harvested on glass-fiber filters. The filters were dried and the incorporated radioactive material was measured in $10 \mathrm{ml}$ scintillation fluid in a beta-counter (Fuji, Rodgan, Germany). All experiments with growth factors, octreotide (Novartis) and BIM23027 (Sigma) were carried out under hypoxic conditions. After maintenance of cells for $24 \mathrm{~h}$ in the serum-free medium, cultures were simultaneously treated with $1 \mu \mathrm{Ci} / \mathrm{ml}\left[{ }^{3} \mathrm{H}\right]$ thymidine and one or the combination of the following factors: VEGF $(20 \mathrm{ng} /$ $\mathrm{ml})$, IGF-1 (20 ng/ml), bFGF (10 ng/ml), TGF $\beta_{2}(50 \mathrm{ng} /$ $\mathrm{ml})$, octreotide $\left(10^{-5}\right.$ to $\left.10^{-10} \mathrm{M}\right)$ and BIM23027 $\left(10^{-7} \mathrm{M}\right)$. All growth factors were obtained from R\&D Systems (Wiesbaden, Germany). Each experiment was performed with cultures from at least three independent experimental set-ups. All cultures were used after the third replate.

\section{Total RNA isolation and RT-PCR}

Total RNA was isolated from $35 \mathrm{~mm}$ culture dishes of BREC using PeqGold RNAPure (Peqlab, Erlangen, Germany) according to the manufacturer's instruc- tions. The RNA concentration was calculated from UV absorbance of RNA solution measured at $260 \mathrm{~nm}$. A total of $10 \mu \mathrm{g}$ of RNA was reverse transcribed at $37^{\circ} \mathrm{C}$ for $2 \mathrm{~h}$ using $200 \mathrm{U}$ of M-MLV (Promega) and $2 \mu \mathrm{g}$ random hexamer primers (Interactivaq, Ulm, Germany). Similarly, a sister reaction containing $10 \mu \mathrm{g}$ of RNA was set up in which M-MLV reverse transcriptase was omitted. PCR was performed with $2 \mu \mathrm{l}$ of the obtained templates in a total volume of $50 \mu \mathrm{l}$ in the presence of 20 pmoles of the respective primers using recombinant Taq polymerase (Gibco). PCR amplification included 35 cycles of denaturation at $95^{\circ} \mathrm{C}$ for $30 \mathrm{~s}$, annealing at $60^{\circ} \mathrm{C}$ for $30 \mathrm{~s}$ and elongation at $72{ }^{\circ} \mathrm{C}$ for $30 \mathrm{~s}$. The quality of the RT reactions was proved by amplification of the GAPDH housekeeping gene with GAPDH-sense primer 5'-GCAC AGTCAAGGCAGAGAACG-3' and GAPDH-antisense primer: 5'-GGTCATAAGTCCCTCCACGAT-3' (338 bp product). The SSTR-2 cDNA was detected using the sequences of the bovine somatostatin receptor primers provided by Novartis (sense primer: 5 '-TGAAGTCCTC CGGCATCCGAGT-3'; antisense primer: 5'-CCGCT CACCTTGACCAAGCAGA-3'; product size: 298 bp). Reaction products were separated on $1.5 \%$ agarose gel in TAE buffer and stained with ethidium bromide.

\section{Western blot analysis}

For immunoblot analysis, cultured BREC were lysed by ultrasonification in $60 \mathrm{mM}$ Tris- $\mathrm{HCl}$, containing $2 \%$ SDS and $10 \%$ sucrose. Protein content of cell lysates was determined using the BCA protein estimation kit (Pierce, 
A

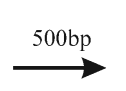

\section{Reverse transcriptase}

Figure 2 Expression of somatostatin/octreotide receptor 2 in bovine retinal endothelial cells. (A) RT-PCR analyses revealed a single 298 bp product of SSTR2 mRNA. Additionally, a 338 bp product of GAPDH mRNA was amplified as an internal control using the same RT reaction as a template. (B) Western blotting using SSTR2-specific antibodies revealed a single immunoreactive protein band with an approximate molecular mass of $60 \mathrm{kDa}$.

Rockford, IL, USA) and BSA as a standard. Cell lysates were diluted $1: 1$ in sample buffer $(250 \mathrm{mM}$ Tris-HCl, $\mathrm{pH}$ $6 \cdot 8$, containing $4 \%$ SDS, $10 \%$ glycerol and $2 \%$ $\beta$-mercaptoethanol) and denatured at $95^{\circ} \mathrm{C}$ for $5 \mathrm{~min}$. Proteins $(15 \mu \mathrm{g} /$ lane) were separated by SDS- $(10 \%)$ polyacrylamide gel electrophoresis and transferred to nitrocellulose by semidry electroblotting. Nonspecific binding sites were blocked with 5\% non-fat milk for $30 \mathrm{~min}$, and then the blots were incubated overnight at $4{ }^{\circ} \mathrm{C}$ with rabbit affinity purified anti-SSTR2 (1:500; Acris, Hiddenhausen, Germany). The immunoreaction was detected by incubating blots for $2 \mathrm{~h}$ at room temperature with anti-rabbit HRP-labeled secondary antibodies (Dianova, Hamburg, Germany) and was visualized with the enhanced chemiluminescence kit (Amersham).

\section{Statistics}

Statistical analysis was performed using the two-sample $t$-test for the means. A value of $P<0.05$ was considered to be statistically significant.

\section{Results}

To measure the effects of growth factors on proliferation of BREC under hypoxia, confluent BREC cultures were treated with bFGF, VEGF, IGF-1 and TGF $\beta_{2}$ at concentrations of $1,5,10,20$ and $50 \mathrm{ng} / \mathrm{ml}$ in serum-free medium and the additional presence of $1 \mu \mathrm{Ci} /$ well of $\left[{ }^{3} \mathrm{H}\right]$ thymidine for $24 \mathrm{~h}$. Liquid scintillation counting of the cell lysates revealed dose-dependent effects of the

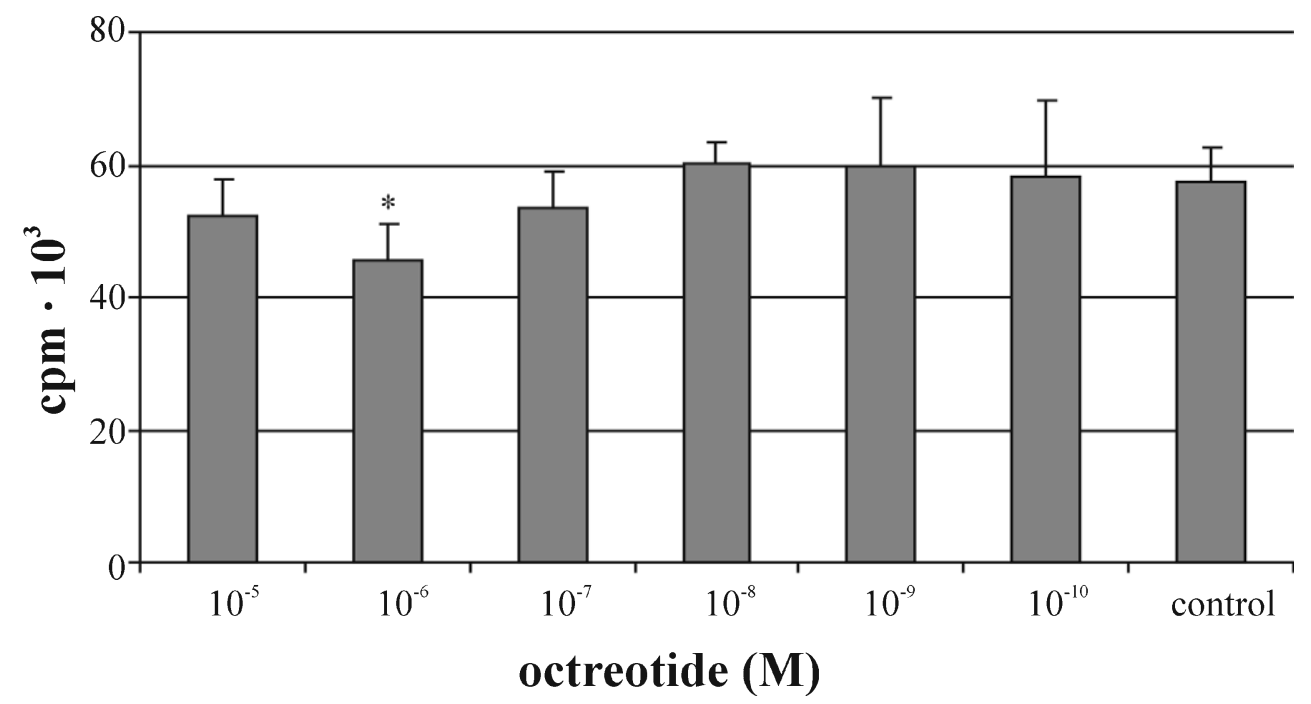

Figure 3 BREC proliferation in response to octreotide in hypoxic conditions. Confluent BREC cultures were incubated with octreotide for $24 \mathrm{~h}$, and the cell proliferation was determined by $\left[{ }^{3} \mathrm{H}\right]$ thymidine incorporation. Maximal effective concentration of $10^{-6} \mathrm{M}$ octreotide inhibited basal proliferation of BREC by $20 \%\left(n=3 ;{ }^{*} P<0 \cdot 0001\right)$. 
A

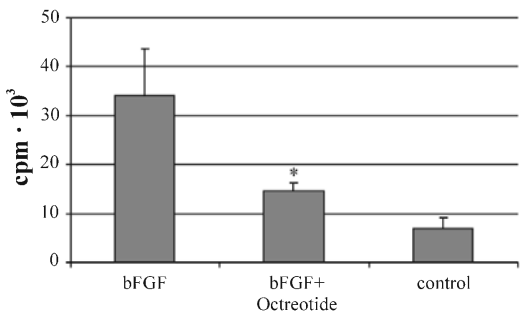

C

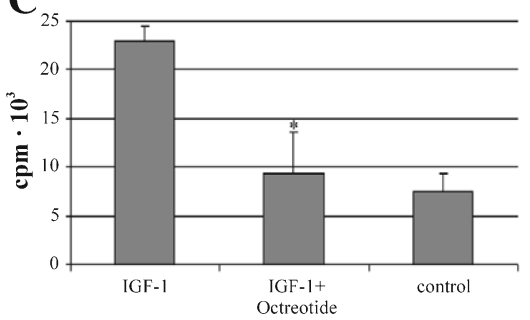

B

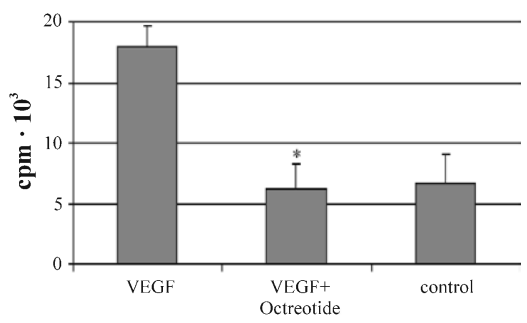

D

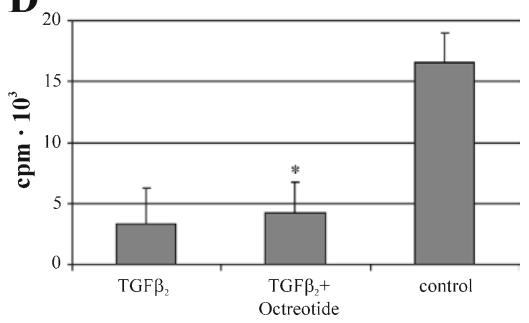

Figure 4 Octreotide inhibits BREC proliferation induced by bFGF, VEGF and IGF-1. BREC were co-treated with combinations of octreotide $\left(10^{-6} \mathrm{M}\right)$ and bFGF $(10 \mathrm{ng} / \mathrm{ml})$, VEGF $(20 \mathrm{ng} / \mathrm{ml})$, IGF-1 $(20 \mathrm{ng} / \mathrm{ml}), \mathrm{TGF} \beta_{2}(50 \mathrm{ng} / \mathrm{ml})$ or growth factors alone, and analyzed for $\left[{ }^{3} \mathrm{H}\right]$ thymidine incorporation. Octreotide massively inhibited the proliferation induced by bFGF (A), VEGF (B) and IGF-1 (C) as compared with treatment with growth factor alone. Octreotide did not further affect the proliferation decreased by $\mathrm{TGF}_{2}$ (D) $(n=3$; $\left.{ }^{*} P<0 \cdot 0001\right)$.

various growth factors on BREC proliferation. bFGF at a concentration of $10 \mathrm{ng} / \mathrm{ml}$ resulted in a maximal $2 \cdot 7 \pm 0 \cdot 6$-fold $(n=3 ; P<0 \cdot 0001)$ increase of endothelial cell proliferation as compared with the control (Fig. 1A). With increasing bFGF concentration $(50 \mathrm{ng} / \mathrm{ml})$, cell proliferation declined but was still significantly increased as compared with control $(n=3 ; P<0 \cdot 0001)$. For VEGF, BREC proliferation was maximal with $20 \mathrm{ng} / \mathrm{ml}$ $(2 \cdot 2 \pm 0.6$-fold; $n=3 ; \quad P<0.0001)$ and declined in the presence of $50 \mathrm{ng} / \mathrm{ml}(1 \cdot 6 \pm 0.6$ fold; $n=3 ; P<0 \cdot 001)$ of the growth factor (Fig. 1B). IGF-1 resulted in a maximal cell proliferation with $20 \mathrm{ng} / \mathrm{ml}(3 \cdot 8 \pm 1 \cdot 8$ fold; $n=3$; $P<0 \cdot 0001)$ and a slight drop of proliferation with $50 \mathrm{ng} /$ $\mathrm{ml}$ (Fig. 1C). In contrast, BREC proliferation was potently decreased upon TGF $\beta_{2}$ treatment at all concentrations tested $(n=3 ; P<0 \cdot 0001)$ (Fig. 1D).

In a subsequent set of experiments, we sought to determine the proliferative response of BREC to costimulation with octreotide and growth factors under hypoxia. The expression of SSTR2, the target receptor for octreotide in BREC, was confirmed by RT-PCR amplification with specific primers and by Western blotting using specific antibodies (Fig. 2). The antibody detected a single protein band with an approximate weight of $60 \mathrm{kDa}$ (He et al. 1989, Thermos et al. 1989). Additional PCR reactions using both SSTR2- and GAPDH-specific primers were performed on templates resulting from control reverse transcription reaction where reverse transcriptase was omitted. Both reactions yielded no PCR products, indicating that RNA preparations were free of contaminating DNA (Fig. 2). To determine maximal effective concentrations of octreotide, confluent endothelial cell cultures were maintained with octreotide $\left(10^{-5}\right.$ to $\left.10^{-10} \mathrm{M}\right)$, and cell proliferation was assessed by $\left[{ }^{3} \mathrm{H}\right]$ thymidine incorporation. Octreotide at a concentration of $10^{-6} \mathrm{M}$ inhibited the basal proliferation of BREC by $20 \%(n=3 ; P<0 \cdot 0001)$ (Fig. 3). Cotreatment experiments further revealed that octreotide massively inhibited the proliferation induced with $10 \mathrm{ng} /$ $\mathrm{ml}$ of bFGF by $50 \% \quad(n=3 ; P<0 \cdot 0001), 20 \mathrm{ng} / \mathrm{ml}$ of VEGF by $60 \%(n=3 ; P<0 \cdot 0001)$ and $20 \mathrm{ng} / \mathrm{ml}$ of IGF-1 by $60 \%(n=3 ; P<0 \cdot 0001)$ (Fig. $4 \mathrm{~A}-\mathrm{C})$. In contrast, co-treatment with octreotide $\left(10^{-6} \mathrm{M}\right)$ and $\mathrm{TGF} \beta_{2}$ $(50 \mathrm{ng} / \mathrm{ml})$ did not further reduce proliferation of BREC as compared with single treatment with TGF $\beta_{2}$ (Fig. 4D). The comparison to BREC cultures maintained under normoxia further revealed that TGF $\beta_{2} \quad(50 \mathrm{ng} / \mathrm{ml})$ basically abolished hypoxia-induced BREC proliferation $(n=3 ; P<0 \cdot 0001)$, whereas octreotide $\left(10^{-6} \mathrm{M}\right)$ only slightly interfered with BREC proliferation induced by hypoxia (Fig. 5). In addition our studies revealed a statistically significant $(n=3 ; P<0 \cdot 01)$ difference between BREC proliferation under normoxia and hypoxia/TGF $\beta_{2}$ (Fig. 5).

To substantiate the role of SSTR2 in octreotide effects, we have additionally determined the growth factorinduced proliferation of BREC in the presence of the SSTR2 receptor agonist BIM23027. Comparably to 


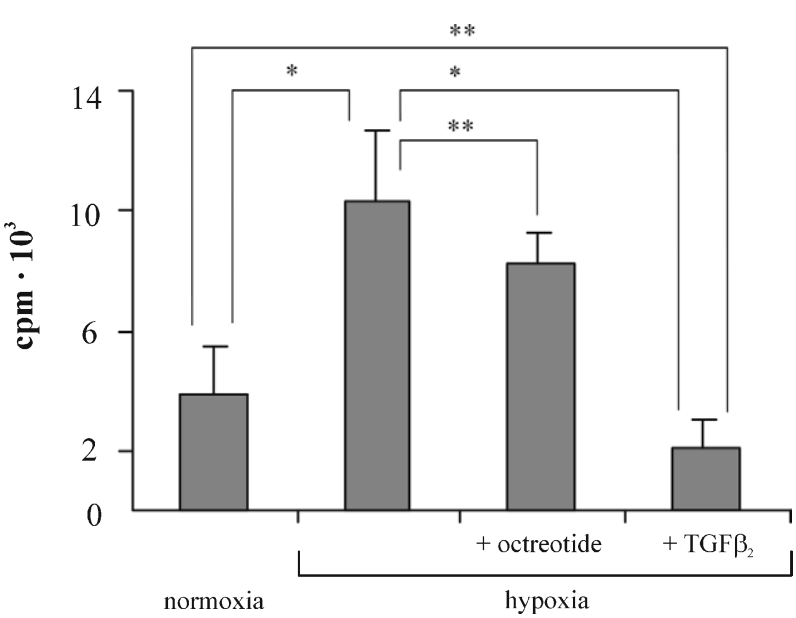

Figure $5 \mathrm{TGF} \beta_{2}$ attenuates hypoxia-induced BREC proliferation. The confluent cultures of BREC were incubated under normoxia $\left(21 \% \mathrm{O}_{2}\right)$ and hypoxia $\left(5 \% \mathrm{O}_{2}\right)$ in serum-free medium for $24 \mathrm{~h}$. Subsequently, the cells were incubated with $1 \mu \mathrm{Ci} / \mathrm{ml}$ $\left[{ }^{3} \mathrm{H}\right]$ thymidine in the presence or absence of TGF $\beta_{2}(50 \mathrm{ng} / \mathrm{ml})$ or octreotide $\left(10^{-6} \mathrm{M}\right)$ for another $24 \mathrm{~h}$. The incorporation of $\left[{ }^{3} \mathrm{H}\right]$ thymidine was determined by liquid scintillation counting. Note that octreotide only slightly interferes with BREC proliferation induced by hypoxia. The results were as follows: hypoxia vs normoxia $\left(n=3 ;{ }^{*} P<0 \cdot 0001\right) ; \operatorname{TGF} \beta_{2}$ in hypoxia vs hypoxia $(n=3 ; * P<0 \cdot 0001) ; \operatorname{TGF}_{2}$ in hypoxia vs normoxia $(n=3$; $\left.{ }^{* *} P<0 \cdot 01\right)$; octreotide in hypoxia vs hypoxia $\left(n=3 ;{ }^{* *} P<0 \cdot 01\right)$.

octreotide, BIM23027 $\left(10^{-7} \mathrm{M}\right)$ strongly inhibited the proliferation induced with $10 \mathrm{ng} / \mathrm{ml}$ of bFGF by $59 \%$ $(n=3 ; P<0 \cdot 001), 20 \mathrm{ng} / \mathrm{ml}$ of VEGF by $60 \%(n=3$; $P<0.002)$ and $20 \mathrm{ng} / \mathrm{ml}$ of IGF-1 by $38 \% \quad(n=3$; $P<0 \cdot 0001$ ) (Fig. 6A-C). BIM23027 at this concentration was shown maximally to induce contractile action in rat isolated distal colon (McKeen et al. 1994).

\section{Discussion}

In our present study, we have investigated the influence of growth factors on proliferation of BREC under hypoxic conditions. We have further determined how octreotide, an analog of somatostatin, modulates the proliferative response of endothelial cells to VEGF, bFGF, IGF-1 and TGF $\beta_{2}$ under hypoxia. Hypoxia is the major cause of many proliferative ocular diseases. Hypoxia affects proliferation of endothelial cells independently of growth factor action through mTOR signaling pathways and induction of genes such as cyclin $D$, which results in $G_{1}$ cell cycle arrest (Gardner et al. 2001). According to the recently proposed model, intracellular signals induced by growth factors converge on hypoxic pathways, resulting in additional effects on cell proliferation.

We have observed a massive change of BREC proliferation under hypoxia. We further observed that under hypoxic conditions VEGF, bFGF and IGF-1 are able, dose dependently, to increase BREC proliferation as compared with hypoxic control. Relatively high concentrations of each growth factor were needed to evoke changes in cell proliferation. Therefore, it seems rather unlikely that the cells produce sufficient growth factor amounts over 1 day under hypoxic conditions to alter significantly their proliferation as compared with normoxia-incubated cells. Consequently, we suggest that the proliferation of untreated BREC cultures was stimulated by hypoxic pathways, rather than indirectly through growth factor upregulation.

Intriguingly, octreotide rather specifically interferes with growth factor-induced BREC proliferation. This conclusion is essentially based on the finding that under hypoxic conditions octreotide prevented growth factorinduced cell proliferation, but exerted only marginal effects on hypoxia-induced increases in BREC numbers. Ongoing studies further demonstrated that in addition to hypoxia, octreotide can also abolish growth factor-induced proliferation of BREC under normoxia (unpublished observations). This rather selective action of octreotide on growth factor-controlled endothelial cell proliferation could also explain why octreotide is ineffective in treating non-proliferative retinopathies which are not evoked by growth factor overproduction (van Hagen et al. 2000). In further support of this view, other recent studies found that inhibition of neovascularization by octreotide results from a direct inhibition of bFGF or IGF-1 activity on endothelial cells (Grant et al. 1993a, Danesi et al. 1997, Spraul et al. 2002).

Unlike octreotide, TGF $\beta_{2}$ attenuated hypoxia-induced BREC proliferation, thus pointing to a hypothetical mechanism in which TGF $\beta_{2}$ directly affects hypoxia-induced genes controlling cell proliferation. In fact, it has been shown that $\mathrm{TGF}_{2}$ can decrease hypoxia-induced cell proliferation by downregulating tumor promoter-induced tubule formation in collagen matrices (Mueller et al. 1987). However, since Emmanuel et al. (2002) have demonstrated that $\mathrm{TGF} \beta_{2}$ evokes apoptosis in endothelial cells, we cannot completely rule out that the low proliferation rate seen in TGF $\beta_{2}$-treated BREC cultures is due to increased cell death. Hogg et al. (1999) have shown that TGF $\beta$, serum deprivation and hypoxia as individual conditions induce apoptosis in vascular endothelial cells to some extent, and they have also reported a pronounced increase in apoptotic cell death upon combination of the various conditions, such as treatment with $\mathrm{TGF} \beta_{2}$ under hypoxia.

Octreotide shows high affinity binding for SSTR2, a somatostatin receptor subtype expressed by BREC, but also binds with lower affinity to SSTR 5 (Bruns et al. 2000). A major role of SSTR 2 in the observed inhibitory effects of octreotide on growth factor-induced BREC proliferation is confirmed by the additional finding that the proliferative response is equally sensitive to the SSTR2 receptor agonist BIM23027. 
A
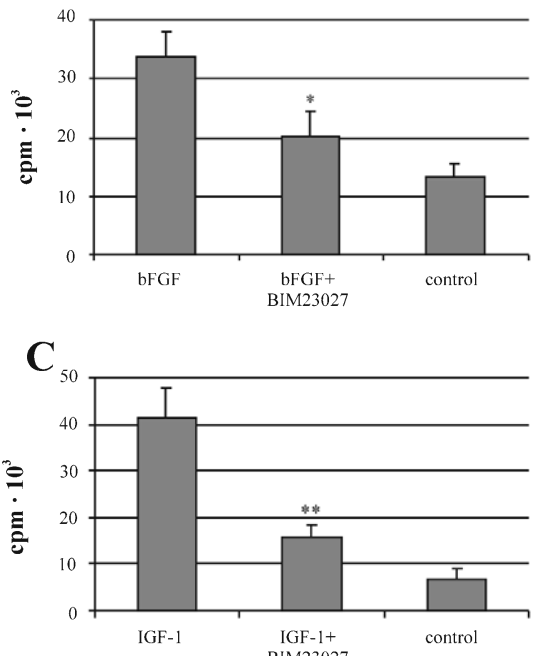

B

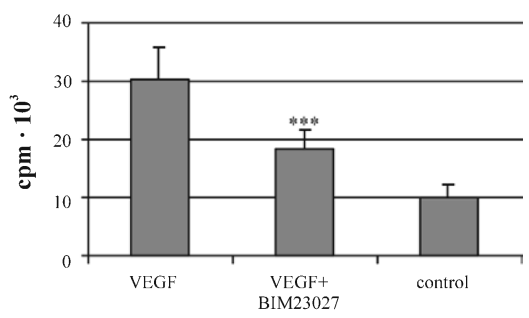

Figure 6 BIM23027 mimics the inhibitory effects of octreotide on growth factor-induced BREC proliferation. BREC were co-treated with combinations of BIM23027 $\left(10^{-7} \mathrm{M}\right)$ and bFGF $(10 \mathrm{ng} / \mathrm{ml})$, VEGF $(20 \mathrm{ng} / \mathrm{ml})$, IGF-1 $(20 \mathrm{ng} / \mathrm{ml})$, TGF $\beta_{2}(50 \mathrm{ng} / \mathrm{ml})$ or growth factors alone, and analyzed for $\left[{ }^{3} \mathrm{H}\right]$ thymidine incorporation. BIM23027 inhibited the proliferation induced by bFGF (A), VEGF (B) and IGF-1 (C) as compared with treatment with growth factor alone $\left(n=3 ;{ }^{*} P<0 \cdot 0001,{ }^{* *} P<0 \cdot 001,{ }^{* * *} P<0 \cdot 002\right)$.

The observation that octreotide potently inhibits growth factor-induced BREC proliferation under hypoxic conditions suggests that octreotide could be a powerful drug against eye disorders where proliferation of retinal endothelial cells is growth factor-dependent. The effectiveness of this treatment can be further increased by also targeting TGF $\beta_{2}$ receptors, which would further prevent hypoxia-induced proliferation of endothelial cells.

\section{Acknowledgments}

We are grateful to Prof. Jürgen Engele for his careful reading of the manuscript, and fruitful comments and suggestions.

\section{References}

Antonelli-Orlidge A, Saunders KB, Smith SR \& D'Amore PA 1989 An activated form of TGF- $\beta$ is produced by co-cultures of endothelial cells and pericytes. PNAS 86 4544-4548.

Battegay EJ 1995 Angiogenesis: mechanistic insights, neovascular diseases, and therapeutic prospects. Journal of Molecular Medicine $\mathbf{7 3}$ 333-346.

Bensaid M, Tahiri-Jouti N, Cambillau C \& Viguerie N 1992 Basic fibroblast growth factor induces proliferation of a rat pancreatic cancer cell line: inhibition by somatostatin. International Journal of Cancer 50 796-804.

Boehm BO, Lang GK, Jehle PM, Feldmann B \& Lang GE 2001 Octreotide reduces vitreous hemorrhage and loss of visual acuity risk in patients with high-risk proliferative diabetic retinopathy. Hormone and Metabolic Research 33 300-306.
Bruns C, Shi V, Hoyer D, Schuurman H \& Weckbecker G 2000 Somatostatin receptors and the potential use of Sandostatin ${ }^{\mathrm{R}}$ to interfere with vascular remodelling. European Journal of Endocrinology 143 3-7.

Buscail L, Esteve JP, Saint-Laurent N, Bertrand V, Reisine T, O'Carroll AM, Bell GI, Schally AV, Vaysse N \& Susini C 1995 Inhibition of cell proliferation by the somatostatin analogue RC-160 is mediated by somatostatin receptor subtypes SSTR 2 and SSTR 5 through different mechanisms. PNAS 92 1580-1584.

Campochiaro PA 2000 Retinal and choroidal neovascularization. Journal of Cellular Physiology 184 301-310.

D’Amore PA 1994 Mechanisms of retinal and choroidal neovascularization. Investigative Ophthalmology and Visual Science 35 3974-3979.

Danesi R, Agen C, Benelli U, Di Paolo A, Nardini D, Bocci G, Basolo F, Campagni A \& Del Tacca M 1997 Inhibition of experimental angiogenesis by the somatostatin analogue octreotide acetate (SMS:201-995). Clinical Cancer Research 26 265-272.

Das M, Bouchey DM, Moore MJ, Hopkins DC, Nemenoff RA \& Stenmark KR 2001 Hypoxia-induced proliferative response of vascular adventitial fibroblasts is dependent on $G$ protein-mediated activation of mitogen-activated protein kinases. Journal of Biological Chemistry 276 15631-15640.

Davis MI, Wilson SH \& Grant MB 2001 The therapeutic problem of proliferative diabetic retinopathy: targeting somatostatin receptors. Hormone and Metabolic Research 33 295-299.

Emmanuel C, Foo E, Medbury H, Matthews J, Comis A \& Zoellner H 2002 Synergistic induction of apoptosis in human endothelial cells by tumor necrosis factor-alpha and transforming growth factor-beta. Cytokine 18 237-241.

Feldmann B, Jehle PM, Mohan S, Lang GK, Lang GE, Brueckel J \& Boehm BO 2000 Diabetic retinopathy is associated with decreased serum levels of free IGF-I and changes of IGF-binding proteins. Growth Hormone and IGF Research 10 53-59.

Gardner LB, Li Q, Park MS, Flanagan WM, Semenza GL \& Dang CV 2001 Hypoxia inhibits G1/S transition through regulation of p27 expression. Journal of Biological Chemistry 276 7919-7926. 
Gerber HP, Condorelli F, Park J \& Ferrara N 1997 Differential transcriptional regulation of the two vascular endothelial growth factor receptor genes. Flt-1, but not Flk-1/KDR, is up-regulated by hypoxia. Journal of Biological Chemistry 272 23659-23667.

Gospodarowicz D, Ferrara N, Schweigerer L \& Neufeld G 1987 Structural characterization and biological functions of fibroblast growth factor. Endocrine Reviews 8 95-114.

Grant MB, Russell B, Fitzgerald C \& Merimee TJ 1986 Insulin-like growth factors in vitreous. Studies in control and diabetic subjects with neovascularization. Diabetes 35 416-420.

Grant M, Jerdan J \& Merimee TJ 1987 Insulin-like growth factor-I modulates endothelial cell chemotaxis. Journal of Clinical Endocrinology and Metabolism 65 370-371.

Grant MB, Caballero S \& Millard WJ 1993a Inhibition of IGF-1 and bFGF stimulated growth of human retinal endothelial cells by the somatostatin analogue, octreotide: a potential treatment for ocular neovascularization. Regulatory Peptides 48 267-278.

Grant MB, Mames RN, Fitzgerald C, Ellis EA, Caballero S, Chegini N \& Guy J $1993 b$ Insulin-like factor I acts as an angiogenic agent. In vivo and in vitro studies. Annals of the New York Academy of Sciences 692 230-242.

Hackett SF, Wiegand S, Yancopoulos G \& Campochiaro PA 2002 Angiopoietin-2 plays an important role in retinal angiogenesis. Journal of Cellular Physiology 192 182-187.

van Hagen PM, Baarsma GS, Mooy CM, Ercoskan EM, Ter Averst E, Hofland LJ, Lamberts SWJ \& Kuijpers RWAM 2000 Somatostatin and somatostatin receptors in retinal diseases. European Journal of Endocrinology 143 43-51.

He HT, Johnson K, Thermos K \& Reisine T. 1989 Purification of a putative brain somatostatin receptor. PNAS 86 1480-1484.

Hogg N, Browning J, Howard T, Winterford C, Fitzpatrick D \& Gobe G 1999 Apoptosis in vascular endothelial cells caused by serum deprivation, oxidative stress and transforming growth factor-beta. Endothelium 7 35-49.

Hughes S, Yang H \& Chan-Ling T 2000 Vascularization of the human fetal retina: roles of vasculogenesis and angiogenesis. Investigative Ophthalmology and Visual Science 41 1217-1228.

Humar R, Kiefer FN, Berns H, Resink TJ \& Battegay EJ 2002 Hypoxia enhances vascular cell proliferation and angiogenesis in vitro via rapamycin (mTOR)-dependent signaling. FASEB Journal 16 771-779.

Jones JI \& Clemmons DR 1995 Insulin-like growth factors and their binding proteins: biological actions. Endocrine Reviews 16 3-34.

Katsura M, Mishima HK, Minamoto A, Ishibashi F \& Yamashita H 2000 Growth regulation of bovine retinal pericytes by transforming growth factor- $\beta 2$ and plasmin. Current Eye Research 20 166-172.

King GL, Buzney SM, Kahn CR, Hetu N, Buchwald S, Macdonald SG \& Rand LI 1983 Differential responsiveness to insulin of endothelial and support cells from micro- and macrovessels. Journal of Clinical Investigation 71 974-979.

Madri JA, Pratt BM \& Tucker AM 1988 Phenotypic modulation of endothelial cells by transforming growth factor-beta depends upon the composition and organization of the extracellular matrix. Journal of Cellular Biochemistry 106 1375-1384.

McKeen ES, Feniuk W \& Humphrey PP 1994 Mediation by SRIF1 receptors of the contractile action of somatostatin in rat isolated distal colon; studies using some novel SRIF analogues. British Journal of Pharmacology 113 628-634.

Mueller G, Behrens J, Nussbaumer U, Boehlen P \& Birchmeier W 1987 Inhibitory action of transforming growth factor $\beta$ on endothelial cells. PNAS 84 5600-5604.

Rifkin DB, Kojima S, Abe M \& Harpel JG 1993 TGF- $\beta$ : structure, function, and formation. Thrombosis and Haemostasis 70 177-179.

Risau W 1994 Angiogenesis and endothelial cell function. Arzneimittelforschung/Drug Research 44 416-417.

Schmelzle T \& Hall MN 2000 Tor, a central controller of cell growth. Cell 103 253-262.

Spraul CW, Baldysiak-Figiel A, Lang GK \& Lang GE 2002 Octreotide inhibits growth factor-induced bovine choriocapillary endothelial cells in vitro. Graefes Archive for Clinical and Expimental Ophthalmology (Berlin) 240 227-231.

Suzuma K, Takagi H, Otani A \& Honda Y 1998 Hypoxia and vascular endothelial growth factor stimulate angiogenic integrin expression in bovine retinal microvascular endothelial cells. Investigative Ophthalmology and Visual Science 39 1028-1035.

Thermos K, He HT, Wang HL, Margolis N \& Reisine T 1989 Biochemical properties of brain somatostatin receptors. Neuroscience 31 131-141.

Wiedemann P 1992 Growth factors in retinal diseases: proliferative vitreoretinopathy, proliferative diabetic retinopathy, and retinal degeneration. Surgery of Ophthalmology 36 373-383.

Wilson SH, Davis MI, Caballero S \& Grant MB 2001 Modulation of retinal endothelial cell behavior by insulin-like growth factor I and somatostatin analogues: implications for diabetic retinopathy. Growth Hormone and IGF Research 11 (suppl. A) 53-59.

Yan Q, Li Y, Hendrickson A \& Sage EH 2001 Regulation of retinal capillary cells by basic fibroblast growth factor, vascular endothelial growth factor, and hypoxia. In Vitro Cellular and Developmental Biology - Animal 37 45-49.

Received in final form 3 December 2003

Accepted 3 December 2003

Made available online as an

Accepted Preprint 10 December 2003 